\title{
AZ ABRAZÍV VÍZSUGARAS VÁGÁS ALKALMAZHATÓSÁGA FORGÁCSOLÓ MEGMUNKÁLÁSI MÜVELETEKRE
}

\author{
Kun-Bodnár Krisztina - Kundrák János
}

\begin{abstract}
Absztrakt: Napjainkban a vízsugár páratlan a vágási eljárások számos vonatkozásában, és megváltoztatta sok termék gyártásának módját. Az abrazív vízsugár többféle műveletre is képes. A vízsugaras vágás legnagyobb elönye más eljárásokkal szemben, hogy ez egy hideg vágási eljárás, mely nem okoz roncsolódást az anyagban, és gyakorlatilag bármilyen anyag vágására alkalmas. Darabolásra elterjedt a használata. Sokirányú kutatás folyik alkalmazásának kiterjesztésére alakos felületek megmunkálására. A cikk az alternatív abrazív vízsugaras műveletek közül a forgástest megmunkálását tárgyalja részletesebben, hiszen az abrazív vízsugár kiváló tulajdonságai miatt esélyes, hogy ezt az eljárást forgácsoló megmunkálásként is alkalmazzák.
\end{abstract}

Abstract: Today the waterjet is unparalleled in many aspects of cutting and has changed the way many products are manufactured. The abrasive waterjet (AWJ) is capable of a variety of operations. Waterjet cutting is a cold cutting process that does not cause fracturing in the material. Almost any material can be machined by waterjet cutting. While it is often used for cutting larger objects into pieces, extension of its application to free form surfaces is also being investigated from a number of angles. This article discusses the machining of a rotating body using alternative AWJ operations. Due to the excellent properties of the abrasive water jet, this process has potential for use in cutting machining.

Kulcsszavak: vízsugár, abrazív, hideg vágási eljárás, esztergálás, forgástest, forgácsoló megmunkálás Keywords: waterjet, abrasive, cold cutting process, turning, rotating body, cutting machining

\section{Bevezetés}

A megmunkálási folyamatok különböző technológiákat foglalnak magukba, amelyek közül jelentős a vágási technológiák aránya. A vízsugaras vágás elve, hogy egy nagynyomású vízoszlop nagy sebességü vízsugárrá átalakulva, kölcsönhatásba lép a megmunkálandó anyaggal. Kétféle vízsugárral végezhetjük a vágást: tiszta vízzel és abrazív vízsugárral. A második esetben a hozzáadott abrazív anyag (adalék), növeli a vízsugár eróziós hatását, ezáltal a megmunkálható anyagok körét. Az abrazív port kétféleképpen adagolhatjuk: keverö kamrában a vizes fúvókából kilépö sugárhoz, amikor egy másodlagos fúvókában gyorsul fel a víz részecskéihez közel hasonló sebességre (injektoros abrazív vízsugaras vágás, 1 . ábra), vagy a már összekevert por és víz alkotta iszapot juttatunk a vízsugárba (szuszpenziós vágás).

A vízsugaras vágás egyik legnagyobb elönye más technológiákkal szemben, hogy ez egy hideg vágási folyamat, mely nem okoz roncsolódást az anyagban, és gyakorlatilag bármilyen anyag vágására alkalmas, ezért az alkalmazási területe széles. A vízsugaras vágás másik nagy elönye, hogy olyan bonyolult síkgörbét lehet vágni, amely más technológiával nem múködik, így széles körben használják a különböző iparágak, mint a repülögép és a gépjármügyártás. 


\section{1. ábra: Abrazív vízsugaras vágófej}

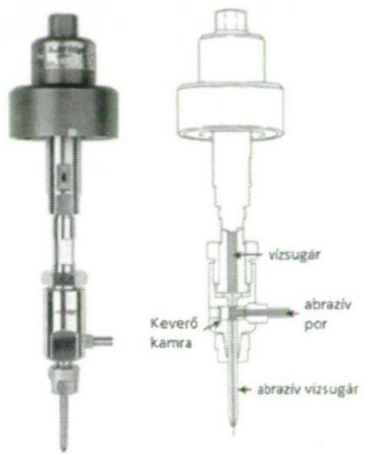

Forrás: Alok Kumar Gharai: Abrasive Jet machining (2012)

Az abrazív vízsugaras megmunkálás lényege egy eróziós folyamat a folyadékban lévő részecskéknek a munkadarabbal történő ütközése és az anyag jellemzőitől függő jelenségek - keményedés, rideg törés, az anyag helyi megolvadása stb. - eredményeként (Tikhomirov, 1992).

Szívós anyagok megmunkálásakor a sugár részecskéi a munkadarab anyagába hatolva, egyenként kismértékü képlékeny alakváltozást okoznak, a becsapódás helyén apró aszimmetrikus kráterek keletkeznek. Rideg anyagok eróziója az abrazív részecskével való ütközés hatására keletkező repedések növekedése és metsződése (összenövése) keletkeztében megy végbe. Akár rideg, akár szívós anyagról van szó, az anyagleválasztás sok egyedi ütközés eredményeként jön létre (Hashish, 1998)

Az eljárás előnyei:

- a vágás során nem keletkeznek környezetre káros anyagok, a vágási felületen nem keletkezik salakanyag

- az anyagminőségek széles köre megmunkálható

- megmunkált vastagság akár $30 \mathrm{~cm}$ is lehet

- a kis vágórésnek (0,03-1,6 mm) köszönhetően minimális az anyagveszteség

- bonyolult alakzatok hozhatók létre

- a vágási felületen nincs hőmérséklet emelkedés

Hátrányai:

- korlátozott a pontossága (a felületek simasága technológiai adat és anyagminőség függő)

- rövid a fúvóka élettartama

- vízpára, fröccsenő anyagok, zajszint megfelelő szinten tartása, géptisztítás időigénye

Az abrazív vízsugaras vágás környezetbarát technológia, jól kiegészíti a hőhatást alkalmazó eljárásokat. Ott alkalmazzák elsősorban, ahol a hőhatással működő eljárások technológiai és gazdasági korlátokba ütköznek. Csaknem minden anyag megmunkálható: a nemfémes anyagok (egyszerủ és szálerősítő müanyagok, gumi, bör, papír, textil), rideg anyagok (páncélüveg, kerámiák, kőzetek, beton, építőipari 
burkolóanyagok), szívós anyagok (színesfémek, vas -és nem vasalapú fémek, tetszőleges hőkezeltségi állapotban), lágy, gyúlékony anyagok, mủanyag habok.

Munkánk célja, olyan berendezés létrehozása, ami lehetővé teszi a felsorolt anyagokból forgásszimmetrikus alkatrészek megmunkálását, az esztergáláshoz hasonló megmunkáló rendszerben.

\section{Forgástest megmunkálása}

A vízsugaras vágás kedvező tulajdonságai miatt mind többen kutatják, milyen megmunkálásoknál és milyen feltételek mellett alkalmazható a vízsugár vágó (forgácsoló) élként. A leggyakrabban a forgácsoló eljárások kinematikai viszonyait alkalmazva tesznek kísérletet alkatrészek megmunkálására. A következőkben forgástest előállításának feltételeiről szólunk.

\subsection{A megmunkálás kinematikája}

A vízsugárral való esztergálás hasonló a hagyományos esztergán, egyélủ szerszámmal végzett esztergáláshoz. A munkadarabot forgatják, miközben a szerszám a forgás tengelyével párhuzamosan halad, és szakaszos fogásvétel történik (Momber-Kovacevic, 1998). A 2. ábrán az abrazív vízsugaras esztergálás néhány paramétere látható. A munkadarabra ható erőhatások elhanyagolhatóak.

\section{2. ábra: Az abrazív vízsugaras vágással történő esztergálás alapelve}

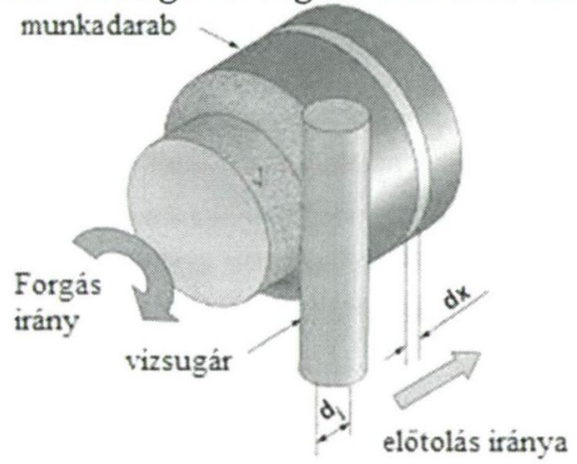

Forrás: Manu-Ramesh Babu (2009)

A fogásmélység több folyamat paraméter függvénye, amely forgácsolási folyamatokhoz hasonló módon határozható meg, természetesen a vízsugaras megmunkálás sajátosságainak figyelembevételével (Manu-Ramesh Babu, 2009).

Az esztergálás kinematikája alapján a forgó főmozgást a munkadarab, míg az elötoló mozgást a szerszám végzi.

2.2. A vízsugaras vágás technológiai paraméterei

A forgácsolás szempontjából meghatározó tervezési és beállítási adatok a $v_{c}$ forgácsoló sebesség, az f előtolás és az $\mathrm{a}_{\mathrm{p}}$, a $\mathrm{a}_{\mathrm{e}}$ fogásmélység, valamint a szerszám, forgácsoló él adatai és a sugár átmérője. 
A vízsugár hatékonyságát meghatározó beállítások (vagy adatok) megválasztásakor különös figyelmet igényel, hogy a megmunkált felület jellemzőit nagyszámú paraméter befolyásolja.

A forgácsoló él, a vízsugár forgácsoló képességét meghatározó adatok beállítását (a víz nyomása és folyadékárama, a vágófej előtoló sebessége, a vizes fúvóka átmérője és geometriai pontossága, az abrazív fúvóka hossza és átmérője, a fúvóka magassága) és az ,élminőséget” (az abrazív por típusa, szemcsemérete, az abrazív tömegáram) az alapberendezéssel biztosítjuk.

Ezen paraméterek közül a legkönnyebben és leggyakrabban változtatható beállítási paraméterek az elötolás, nyomás és az abrazív áram.

\section{A tervezett berendezés és jellemzői}

A forgástestek megmunkálásához abrazív vízsugárral olyan berendezést kell terveznünk, amely megfelel az alábbi szempontoknak:

- vízsugaras berendezésen legyen végrehajtható a megmunkálás és az alapgép biztosítsa az előtolást

- a készülék felfogása stabil legyen

- biztosítsa a munkadarab befogását és a forgómozgást

A tervezés során a munkadarab forgató berendezést három föbb egységre osztottuk: egy hajtómüre, egy vízvédỏ szerkezetre és egy tartószerkezetre.

A hajtómü biztosítja a munkadarab befogását és a meghajtást. Ezt a feladatot egy három pofás eszterga tokmány és szíjtárcsák segítségével valósítjuk meg. Mivel annak vizsgálatát is tervezzük, hogy hogyan befolyásolja a vágott felület minőségét a forgás iránya, ezért irányváltóval terveztük a hajtómüvet. Feladatunk egy vízvédő szerkezet megtervezése is, hogy vágáskor a visszacsapódó víztöl, megvédjük a hajtómüvet. Végül pedig szükségünk van egy tartószerkezetre, ami a vízvágó gép munkaterébe süllyed, és feladata a munkadarab hajtómü rögzítése és pozícionálása a vízvágó gép koordináta rendszeréhez viszonyítva. A tartószerkezet segítségével meghatározható a vízvédő szerkezet helye, figyelembe véve a gép specifikációit, méreteit, a vágófej mozgás tartományát és a szánrendszer méreteit.

$\mathrm{Az}$ alkatrészek tervezése, majd legyártása után összeszerelésre került a 3. ábrán látható forgató berendezés, amelyen egy elsődleges teszt üzempróbát végeztünk, ahol vizsgáltuk a motor teljesítményét, a stabil fordulatszámot, illetve az esetlegesen felmerülő hibákat. Az elöszerelés és a próba üzem alatt igyekeztünk kiküszöbölni minden fellépő és/vagy várható hibát. A szükséges beállítások és módosítások után a munkadarab meghajtó müködöképes, jelenleg folyamatban van az elökísérletek elökészítése. Az ehhez szükséges alkatrészek, munkadarab befogó tüskék, távtartó hüvelyek elkészültek, az első próbadarabok adatai rendelkezésre állnak, egy elsődleges „száraz” üzemet követően sor kerülhet az első kísérleti forgácsolásra. 


\section{3. ábra: A forgató berendezés}

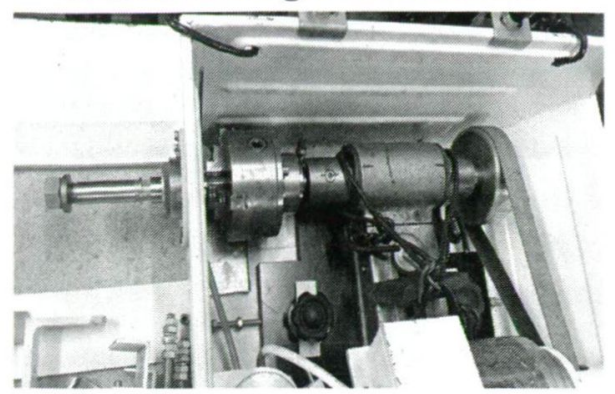

Forrás: A szerző saját szerkesztése (2017)

\section{Következtetések, összegzés, záró megjegyzések, záró gondolatok}

Egy megtervezett és legyártott berendezést mutattunk be, amely a vízsugaras gépen (mint alapgép) lehetővé teszi vízsugaras vágással forgástestek előállítását. A forgástest megmunkáló eljárás feltételeinek optimális kialakítása további kutatómunkát igényel. A következő feladatok állnak előttünk: az abrazív vízsugár vágóélként történő alkalmazására vonatkozó feltételek vizsgálata; a megmunkálási eljárások kinetikai viszonyainak elemzése; az anyageltávolítás geometriai viszonyainak és az anyagleválasztás (felületképzési sebesség) hatékonyságának elemzése.

\section{Köszönetnyilvánítás}

A cikkben ismertetett kutató munka az EFOP-3.6.1-16-2016-00011 jelü „Fiatalodó és Megújuló Egyetem - Innovatív Tudásváros - a Miskolci Egyetem intelligens szakosodást szolgáló intézményi fejlesztése" projekt részeként - a Széchenyi 2020 keretében - az Európai Unió támogatásával, az Európai Szociális Alap társfinanszírozásával valósul meg.

\section{Irodalomjegyzék}

Hashish, M. (1998): The waterjet as a tool. 14th International conference on Jetting Technology, Brugge, Belgium, 1998. szeptember 21-23, ppiXX-iXLIV.

Manu, R., Ramesh Babu, N. (2009): An erosion-based model for abrasive waterjet turning of ductile material. Wear, 266 (11-12): 1091-1097.

Momber, A W., Kovacevic, R. (1998): Principles of Abrasive Water Jet Machining. Springer-Verlag London Ltd., London.

Tikhomirov, R. A. (1992): High-pressure jet cutting. ASME Press, New York. 